\title{
Francis Xavier at the Court of Ōtomo Yoshishige: Representations of Religious Disputation between Jesuits and Buddhists in La conversione alla santa fede del re di Bungo giaponese (1703)
}

\author{
Makoto Harris Takao \\ University of Western Australia \\ makoto.takao@research.uwa.edu.au
}

\begin{abstract}
Throughout the seventeenth and eighteenth centuries, exotic tales of conversion and martyrdom set in Japan played out upon the Jesuit stages of Europe. It is in this way that Japan's Christian Century (1549-1639) endured in the Jesuit mind as a source of spiritual and creative inspiration. The development of the "Japanese genre" in the acted and musical dramas of the historical Society of Jesus is a scarcely travelled road of research. In exploring this unique performance tradition, the article presents an analysis of the only known example of an oratorio based on a solely Japanese theme:La conversione alla santa fede del re di Bungo giaponese (1703). The article addresses the oratorio's literary genealogy in order to identify the librettist's didactic intention. In so doing, the representation of theological disputations between the Jesuits and the various sects of Buddhist priests in the mid-sixteenth century is reconstructed and examined.
\end{abstract}

\section{Keywords}

Jesuits - oratorio - early music - intercultural studies - Japanese studies - Buddhism missiology - early modern history - conversion - La conversione alla santa fede del re di Bungo giaponese

Now that we have a definite knowledge about the contents of their [religious] laws, we are searching for reasons to prove them to be false. Every 
day we have therefore asked them questions about their laws and arguments; but neither the bonzes ${ }^{1}$ nor the nuns, the soothsayers nor any others who are opposed [to] the law of God, have been able to answer them. When the Christians saw that the bonzes could not answer our questions, they were delighted. Every day they came to believe more firmly in God, and the pagans who attended the disputations lost confidence in the erroneous sects in which they had believed. ${ }^{2}$

In this letter to his companions in Europe, Francis Xavier (1506-52) reflected upon the birth of Christianity in the recently-discovered islands of Japan. ${ }^{3}$ Following his arrival on August 15, 1549, Xavier travelled throughout the Kyushu region-visiting the cities of Hirado, Hakata, Funai, and Yamaguchi-and moving as far east as Sakai and Kyoto over a period of twenty-seven months. The consequent seeds of Christian faith sown by Xavier and his missionaries were destined to bloom in uncertain soils during a time of much political unrest. ${ }^{4}$ Until the turn of the seventeenth century, such writings about Japan occupied more space in published collections of Jesuit letters than those about any other Asiatic country. ${ }^{5}$ Despite the eventual suppression of Christianity and the closure of Japan's borders by 1639 , the Jesuit province of Japan continued to be administered from Macao as late as the eighteenth century. While some missionaries hopelessly endeavored to join their brothers in exile, other individuals such as João Rodrigues (1561-1634) unsuccessfully

1 Derived from the Portuguese word bonzo (Buddhist monk), a transliteration from the Japanese $b \bar{o} z u$ (坊主).

2 Francis Xavier to his companions in Europe, from Cochin, January 29, 1552, in Letters and Instructions of Francis Xavier, trans. M. Joseph Costello (St. Louis: Institute of Jesuit Sources, 1992), 333 .

3 Portuguese merchants had discovered the Ryūkū islands in 1542 and later arrived at Tanegashima (Kagoshima, Japan) upon a Chinese junk in 1543. For the 1607 Japanese account of this arrival, see Okamoto Yoshitomo, Jūroku seiki Nichiō kōtsūshi no kenkyū (Tokyo: Kōbunsō, 1936), 187-89.

4 For an overview of Japan's Sengoku Jidai [Warring states period] see Stephen Turnbull, War in Japan, 1467-1615 (Oxford: Osprey, 2002); John Whitney Hall, Nagahara Keiji, and Kōzō Yamamura, eds., Japan before Tokugawa: Political Consolidation and Economic Growth, 1500-1650 (Princeton: Princeton University Press, 1981); Marius B. Jansen, ed., Warrior Rule in Japan (Cambridge: Cambridge University Press, 1995).

5 Donald F. Lach, Asia in the Making of Europe, vol. 1-II (Chicago: University of Chicago Press, 1965), 674 . 
petitioned the Society of Jesus to support efforts to revive missionary activity in Japan. ${ }^{6}$ It is perhaps through the re-imagination of Japan's Christian Century (1549-1639) in European performing traditions that hope for reconquering the Land of the Rising Sun was preserved. Certainly, for composers, librettists, and playwrights of the Society of Jesus, creative inspiration was found in the annals of the Japanese church, replete with heroic tales of conversion and martyrdom amidst adversity, and the endurance against ruthless and systematic persecutions. A discernible genre of what can be called "Japanese plays" throughout Europe can be linked to the beatification of three Japanese Jesuits-Paul Miki (c.1564-97), John de Gotō (1578-97), and James Kisai (1533-97)—by Pope Urban VIII (r.1623-44) in 1627.7 Dramatic and musical works alike drew upon such prominent Japanese figures who dominated Jesuit literature, often contributing to the then established view of Japan's Christian Century as a mirror of the early Roman church. One of these most enduring characters throughout eighteenth-century Europe was the "king" of the province of Bungo. ${ }^{8}$ Recurrently referred to in (mainly French) Jesuit histories as "Civan" 9 the daimyo Otomo Yoshishige (1530-87) held the seat of power in the city of Funai. ${ }^{10}$ With the exception of Takayama Ukon (1552-1615), Yoshishige was arguably the most revered of the Kirishitan ${ }^{11}$ daimyo both during and after his lifetime. The European fame of this Japanese sovereign, "who embraced so heartily the law of God and showed such love to the priests and [the] Portuguese,"12 reflects a man in a state of theological flux between the states of "Catholicness" and "Buddhistness." Indeed, his support of the Jesuits and his eventual baptism in

6 See Charles R. Boxer, The Christian Century in Japan, 1549-1650 (Berkeley: University of California Press, 1951), 320-28; Lach, Asia in the Making of Europe, 173-74; Johannes Laures, The Catholic Church in Japan (Rutland: Charles E. Tuttle, 1954), 164-67.

For the account of their martyrdom along with twenty-three other Christians in Nagasaki on February 5, 1597, see Luís Fróis, De rebus Iaponicis historica relatio (Mainz: Johann Albin, 1599), 1-81.

8 Bungo province (豊後国) of eastern Kyushu, present-day Oita prefecture.

9 See, for instance, Pierre-François-Xavier de Charlevoix, Histoire et description générale du Japon, vol. 1 (Paris: J.M. Gandouin, 1736), 211-29. It is, however, interesting to note that the use of the name "Civan" in La conversione alla santa fede predates its use in any of the Jesuit church histories.

10 Funai (府内), the historical capital of Bungo over which Ōtomo Yoshishige ruled. He also controlled the provinces of Buzen, Chikugo, Chikuzen, and parts of Higo.

11 A transliteration from the Portuguese cristão: a Japanese term for Roman Catholics, it is used today as a historiographic term for Christians in Japan during the sixteenth and seventeenth centuries.

12 Portuguese missionary Luís Fróis's (1532-97) account of Yoshishige, in Heinrich Dumoulin, Zen Buddhism: A History, vol. 2: Japan (New York: Macmillan, 1990), 289. 
1578 has polarized the ways in which history remembers him. ${ }^{13}$ For the historical Society of Jesus, Ōtomo Yoshishige was lauded as a man of virtue, and his legacy as a Christian king grew throughout the eighteenth century in theaters and churches across Europe. ${ }^{14}$ His patronage of the Jesuit mission during its early years afforded missionaries the opportunity to preach and engage with existing religious institutions. In so doing, the roots of the Japanese church were founded on a basis of theological disputation, with the first Jesuits collecting information on a miscellany of Buddhist practices in order to structure arguments against them. This apologetic spirit and a fascination with the exoticism of the Japanese mission would later converge at a juncture in the development of the Italian oratorio. In this way, the cultural distance between the Jesuits' Japanese past and their artistic ventures throughout the seventeenth and eighteenth centuries was mediated through the interpretation and re-interpretation of tales such as that of Ōtomo Yoshishige. In 1703, La conversione alla santa fede del re di Bungo giaponese (The conversion of the Japanese king of Bungo to the holy faith), an oratorio composed by Pietro Paolo Laurenti (1675-1751) with a libretto by "Verbenio," was performed in the Chiesa di Santa Maria dell'Angelo of Faenza (see Figure 1). ${ }^{15}$ While the musical score has been lost, the libretto is preserved today at the Museo Internazionale e Biblioteca della Musica in Bologna (see Figure 2). Although the existence of this text has long been acknowledged since the late-nineteenth century, ${ }^{16}$ it has received

13 Despite the Christian-centric view of Yoshishige as a bastion of Catholic fortitude, his efforts to construct a model Christian state have also been looked back upon with scorn. Yuki Hideo notes that a tourist pamphlet at the Zuihō-in (瑞峯院), a Rinzai sub-temple of Daitoku-ji (大徳寺), founded by Yoshishige in 1546, contains a description of him as a ruthless warlord who exploited his faith: "[...] at the age of fourty-eight [sic], this devoted Zen follower became a fanatic Christian. [...] Ōtomo killed many Buddhist monks and nuns, destroyed many Buddhist temples, seminaries, [and] monasteries." Yuki Hideo, "Christianity and Japanese Culture," Japanese Religions 26, nos. 1 and 2 (2000): 28-35.

14 Immoos discusses the "Bungo cycle" of Swiss baroque plays (including references to some musical works) that focus on the figure of Ōtomo Yoshishige. See Thomas Immoos, "Japanese Themes in Swiss Baroque Drama," in Studies in Japanese Culture, ed. Joseph Roggendorf (Tokyo: Sophia University, 1963), 79-98.

15 The title page of the libretto specifies that the oratorio was "to be sung in the church of the fathers of the aforesaid Society [of Jesus] in Faenza" [da cantarsi nella Chiesa de Padri di detta Compagnia in Faenza]. The Chiesa di Santa Maria dell'Angelo was the first Jesuit church to be built in Faenza, with work beginning in 1621 under the direction of Girolamo Rainaldi (1570-1655), later substituted by Ercole Fichi (1595-1665) in 1646.

16 See Corrado Ricci, I teatri di Bologna nei secoli XVII e XVIII: Storia aneddotica (Bologna: Successori Monti, 1888), 392; Leonida Busi, Il Padre G. B. Martini: Musicista-letterato del secolo XVIII, vol. 1 (Bologna: Zanichelli, 1891), 129. 


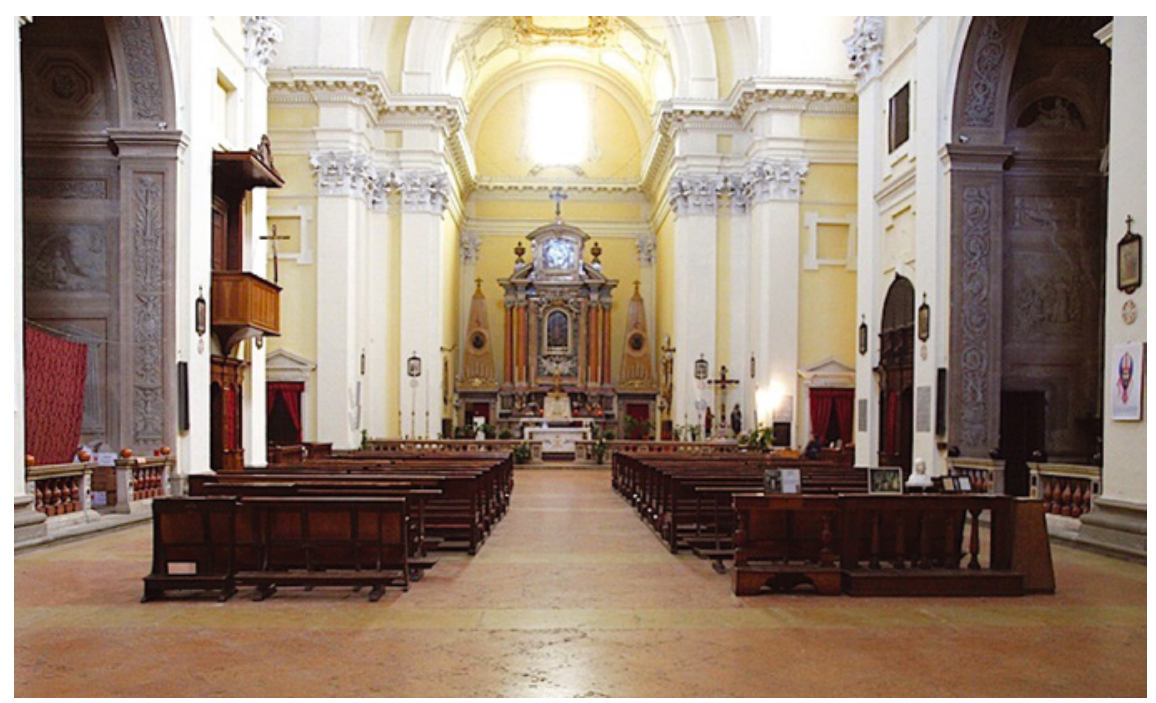

FIGURE 1 Faenza, Church of Santa Maria dell'Angelo

PHOTO WITH PERMISSION OF PRO LOCO FAENZA, WWW.PROLOCOFAENZA.IT

no academic attention to date. As such, this article will explore the hitherto unknown narrative of this libretto while contextualizing it within its historical, musical, literary, and religious settings. In so doing, it will analyze the performative representation of Buddhism and explore the apologetic voice of the librettist through his development of characters and blurring of fact with fiction in the oratorio. What we are ultimately faced with is not an instance of genuine interreligious dialogue (a true kaikō), ${ }^{17}$ but rather one of disputation, where the Jesuit impulse was to identify and magnify comparative theological differences. ${ }^{18}$

17 Kaikō (邂哌), an "encounter" in Japanese. Obara interprets this as a "marvellous encounter" in ancient Japanese. See Satoru Obara, "Jesuit Education in the Kirishitan Period: Francis Xavier's Longing for a 'College in the Capital," in The Future Image of Sophia University: Looking Toward the $21^{\text {st }}$ Century, ed. Mutsuo Yanase (Tokyo: Sophia University, 1989): 25-54, here 25 .

18 Joan-Pau Rubiés, "Real and Imaginary Dialogues in the Jesuit Mission of SixteenthCentury Japan," Journal of the Economic and Social History of the Orient 55 (2012): 44794. See also Kishino Hisashi, "From Dainichi to Deus: the Early Missionaries' Discovery and Understanding of Buddhism," in Christianity and Cultures: Japan and China in Comparison, 1543-1644, ed. M. Antoni J. Üçerler (Rome: Institutum Historicum Societatis Iesu, 2009), 45-6o; Michael Cooper, "The Early Jesuits in Japan and Buddhism," in Portuguese Voyages to Asia and Japan in the Renaissance Period, ed. Peter Milward (Tokyo: Renaissance Institute, Sophia University, 1994), 43-57. 


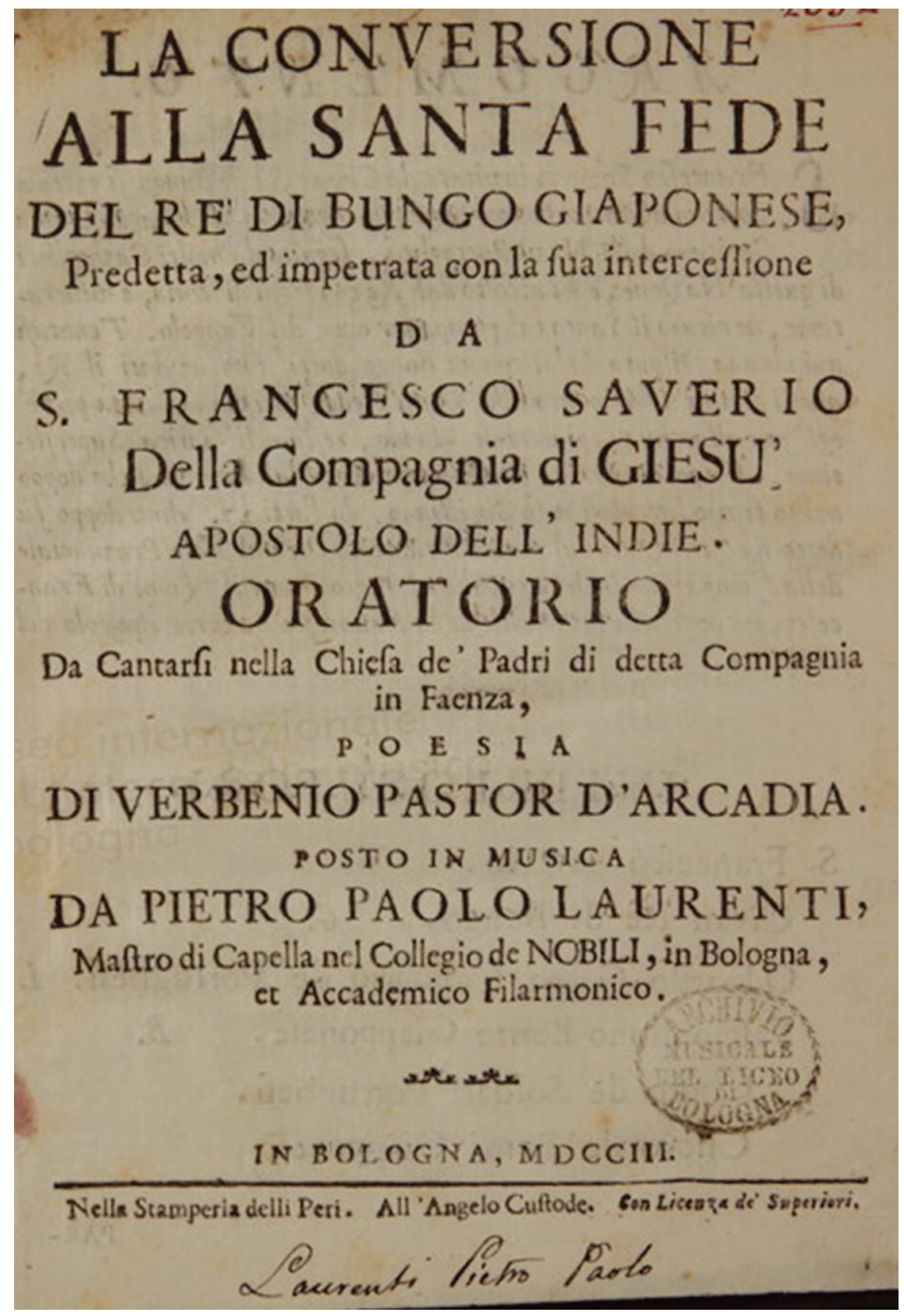

FIGURE 2 Libretto of La conversione alla santa fede del re di Bungo giaponese (Bologna: Nella Stamperia delli Peri, 1703), title page

REPRODUCED WITH PERMISSION OF THE MUSEO INTERNAZIONALE E BIBLIOTECA DELLA MUSICA, BOLOGNA 


\section{The Composition of La conversione alla santa fede del re di Bungo giaponese}

"The Japonians will be our Judges afterwards, and their Example will infallibly confound our Tepidity and Coldness."19 So claimed the French Jesuit Jean Crasset (1618-92) in his Histoire de l'eglise du Japon. The reverence with which the converts and martyrs of Japan's Christian Century were treated found its ultimate manifestation in the performing arts throughout the Baroque period. Indeed, La conversione alla santa fede can be identified as belonging to a genre of "Japanese plays" (musical or otherwise), and appears to be the first and only example of an oratorio based on an entirely Japanese theme. ${ }^{20}$ As early as 1622, however, we find the musical representation of "Japan" among a number of oriental allegories in Giovanni Girolamo Kapsberger's Apotheosis sive consecratio ss. Ignatii et FrancisciXaverii. ${ }^{21}$ By the turn of the eighteenth century, a discernible "Japanese genre" of Jesuit plays and melodramas had become entrenched in the canon of college productions. ${ }^{22}$ Johann Bernhard Staudt's Mulier fortis of 1698 appears to be one of the few examples of this genre with an extant musical score. ${ }^{23}$ The conversion of Ōtomo Yoshishige also appears during the

19 Jean Crasset, The History of the Church of Japan, vol. 2 (London: n.p., 1707), 222.

20 I have been unable to find any other reference to an entirely "Japanese" oratorio. Samuel Coleridge-Taylor's secular cantata A Tale of Old Japan (1911), however, used the poem "Two Painters" by Alfred Noyes as its libretto, while Dudley Buck's cantata The Light of Asia (1886) was based on the epic poem of Edwin Arnold and explored the "life and teaching of Gautama, prince of India and founder of Buddhism."

21 See Victor A. Coelho, "Kapsberger's Apotheosis... of Francis Xavier (1622) and the Conquering of India," in The Work of Opera: Genre, Nationhood, and Sexual Difference, ed. Richard Dellamora and Daniel Fischlin (New York: Columbia University Press, 1997), 27-47; T. Frank Kennedy, liner notes to The Jesuit Operas: Operas by Johannes Kapsberger (Apotheosis sive consecratio ss. Ignatii et Francisci Xaverii) and Domenico Zipoli/Martin Schmid/et al. (San Ignacio), 2-CD set, Dorian Recordings: 3243, 2003.

22 Immoos has identified some 650 performances on Japanese themes in German-speaking countries and in the old Habsburg empire during the early modern period. See Thomas Immoos, "Gratia Hosokawa, Heroine of an Opera in Vienna 1698," in Mission und Theater:Japan und China auf den Bühnen der Gesellschaft Jesu, ed. Adrian Hsia and Ruprecht Wimmer (Regensburg: Schnell und Steiner, 2005), 373-78. See also Goran Proot and Johan Verberckmoes, "Japonica in the Jesuit Drama of the Southern Netherlands," Bulletin of Portuguese-Japanese Studies 5 (2002): 27-47.

23 See Makoto Harris Takao, "In what storms of blood from Christ's flock is Japan swimming?': Performative Representations of the Japanese Female Martyr in Johann Baptist Adolph and Johann Bernhard Staudt's Mulier fortis (1698)," in Changing Hearts: Performing Jesuit Emotions between Europe, Asia, and the Americas, ed. Yasmin Haskell and Raphaële Garrod (Leiden: Brill, forthcoming). 
mid-eighteenth century, among others, in the allegorical drama musicum, Pallas und Flora (Pallas and Flora), performed at the Jesuit college of Luzern in ${ }_{1741 .}{ }^{24}$ The popularity for such Japanese exoticism also made its way into purely secular entertainment. Joseph Bodin de Boismortier's ballet comique, Don Quichotte chez la duchesse (Don Quixote at the duchess, premiered in 1743), for instance, takes inspiration from Cervantes's work, but, through the hand of librettist Charles-Simon Favart, is embellished with fanciful Japanese divertissements. To this extent, the Japanese theme of La conversione alla santa fede was not unique for its time. However, contrasted with the previous examples of Jesuit musical works, this oratorio, which features Japanese characters in sung (as opposed to acted) roles, was something innovative, reflecting also the genre's compositional development in early eighteenth-century Italy.

Following the Apennine earthquakes of 1703, Pope Clement XI (r.1700-21) issued a decree that prohibited popular carnival festivities, including opera, for a period of five years as an expression of gratitude to God for protecting Rome. To fill this cultural void, oratorios were turned to as a source of entertainment which could simultaneously satisfy spiritual needs. ${ }^{25}$ Having developed closely to opera, both in the treatment of libretto and musical aesthetic, oratorios were effective and affective substitutes for the banned operas up until $1709 .{ }^{26}$ As has

24 Die Danck-Sagende Pallas und Heyl-Eyfferende Flora (Luzern: Jost Frantz Jacob Wyssing, 1741). In this drama musicum, Flora, the Roman goddess of flowers, is an allegory for the Japanese church, who despite rejoicing in her many Japanese martyrs, is discouraged by the inability of a plant to blossom. The conversion of Ōtomo Yoshishige is represented onstage through the blooming of a purple flower.

25 The term "oratorio" has taken on a variety of different definitions since the seventeenth century. It can, however, be generally defined as an extended composition based on a libretto having a religious theme and performed by a chorus, orchestra, and vocal soloists, in concert and church contexts.

26 Howard E. Smither, A History of the Oratorio, vol. 1 (Chapel Hill: University of North Carolina Press, 1977), 258-80. One might even say that it was through these oratorios that opera survived in Rome during those years. Handel's La resurrezione (HWV 47), for instance, performed on Easter Sunday of 1708 at the Palazzo Ruspoli, was produced with rich tapestries, palms, and canvas backdrops, among other ornaments. This "closet" opera caused great scandal with Clement XI not for its extravagance, but because of Handel's use of female singers, in defiance of another decree of 1704, which forbade the participation of women in public performances. See, for instance, Francesco Valesio's account (April 9, 1708) of Clement XI's response to the oratorio in George Frideric Handel: Collected Documents, ed. Donald Burrows et al., vol. 1 (Cambridge: Cambridge University Press, 2013), 127. 
been demonstrated by van der Linden, the ambiguous identity of the Italian oratorio, as being somewhere between the secular and sacred, was also a defining characteristic of the musical form. ${ }^{27}$ Indeed, this ambiguity allowed for the oratorio to occupy various performance contexts, gaining particular popularity during Clement's prohibition period of the early eighteenth century. ${ }^{28}$ It was while this edict was in force that $L$ a conversione alla santa fede was written by Laurenti and "Verbenio." Pietro Paolo Laurenti was noted during his lifetime as a skilled string player, singer, and composer. ${ }^{29}$ Having studied under Giacomo Antonio Perti (1661-1756), Laurenti was recognized for his compositions both secular and sacred. Looking at his operatic output, by 1709, Laurenti had written only one opera after his first production of 1701 (Attilio Regolo in Affrica, [Marcus] Atilius Regulus in Africa). With nine oratorios composed between 1703 and 1710 , however, it is clear that during the imposition of Clement XI's edict Laurenti had found his dramatic outlet in the oratorio. While composers such as Handel (1685-1759), Antonio Caldara (1670-1736), and Alessandro Scarlatti (1660-1725) composed oratorios during this prohibition period, their plots were "less operatic," based upon allegorical discourses or colorful sacred and biblical narratives. ${ }^{30}$ Laurenti and Verbenio's oratorio, by virtue of its historical and cultural exoticism, thus holds a unique place in this genre's history. Without the musical score of La conversione alla santa fede to analyze, what we are left with is the sophisticated poetics of the libretto by "Verbenio, pastor d'Arcadia." ${ }^{31}$

27 Huub van der Linden, "The Unexplored Giant: Use Histories of Italian Oratorio around 1700" (PhD diss., European University Institute, 2012).

28 See Stefanie Tcharos, Opera's Orbit: Musical Drama and the Influence of Opera in Arcadian Rome (Cambridge: Cambridge University Press, 2011), 46-97; Arnaldo Morelli, "La circolazione dell'oratorio italiano nel Seicento," Studi musicali 26 (1997): 105-86; Paola Besutti, ed., L'oratorio musicale italiano e i suoi contesti (secc. XVI-XVIII) (Florence: Olschki, 2002).

29 Laurenti was admitted to the Accademia Filarmonica as a cellist in 1698 and as a composer in 1701. As a singer he was cast in a number of operas including Tomaso Albinoni's $I l$ Giustino of 1711 and Antonio Lotti's Teuzzone, 1711-12. See also Michael Talbot and Enrico Careri, "Pietro Paolo Laurenti," in The New Grove Dictionary of Music and Musicians, ed. Stanley Sadie (London: Macmillan, 2001), 381-82.

30 Cecilia Bartoli has recorded a number of arias from these oratorios: see Cecilia Bartoli, Opera proibita, Decca: CD 4757029, 2005.

31 For a discussion of the Italian oratorio as a literary genre, see Mauro Sarnelli, "Percorsi dell'oratorio per musica come genere letterario fra Sei e Settecento," in Percorsi dell'oratorio romano, da "historia sacra" a melodramma spirituale: Atti della giornata di studi, ed. Saverio Franchi (Rome: IBIMUS, 2002), 137-97. 
Giovanni Tedeschi (1648-1727), not to be confused with the eighteenthcentury castrato of the same name (also known as "Amadori"), was a professor of belles-lettres in Carpi for many years, and was regarded as an influential writer in his time. ${ }^{32}$ "Verbenio" was the Arcadian pseudonym under which Tedeschi published a number of his works. Unlike Laurenti, who was a Franciscan, ${ }^{33}$ Tedeschi was a member of the Society of Jesus. ${ }^{34}$ Laurenti and Tedeschi's choice of Ōtomo Yoshishige as a subject was not only appropriate for their intended audience (the Jesuits' congregation in Faenza), but, by virtue of the exotic setting, also promising in terms of entertainment. The oratorio's argomento summarizes the plot:

Saint Francis Xavier having been invited by Civan, king of Bungo, presented himself at court in noble dress with the cortege of Edward Gama, captain of the Portuguese ships, followed by many knights of the country, and was welcomed by the king with signs of esteem and veneration. The saint did not reject this display of courtly pomp because it honored the Gospel. Having then held a dispute with a very learned bonze before the king, the latter was moved by the holy Christian faith. But because he was tied to the pleasures of the world, he remained in the ancient superstition [Buddhism]. It was then foretold by Xavier, with prophetic spirit, that after a long time the king would become a Christian. In fact, twenty-seven years later, the king was baptized by Father Francis Cabral, vice-provincial of the Society of Jesus, and he chose at the sacred font the name of Francis, in the venerable memory of Saint Francis Xavier, apostle of Japan. ${ }^{35}$

Despite the oratorio's name and the argomento's focus on Yoshishige's baptism, the dramatic action does not actually portray his formal conversion, but rather his meeting with Xavier and a fictitious religious debate between the saint and

32 François-Xavier de Feller, Supplément au dictionnaire historique, vol. 2 (Paris: Méquignon, 1820), 288-89.

33 François Joseph Fétis, Biographie universelle des musiciens et bibliographie générale de la musique, vol. 5 (Paris: Firmin Didot Frères, 1840), 76-77. See also Louis Mayeul Chaudon, Dictionnaire universel: Historique, critique et bibliographique, vol. 17 (Paris: Mame Frères, 1812), 2.

34 "Verbenio" is identified as the Jesuit Tedeschi in a number of eighteenth-century publications. See, for instance, Giovanni Mario Crescimbeni, L'Arcadia (Rome: Antonio de' Roffi alla Piazza di Ceri, 1711), 355; Crescimbeni, Dell'istoria della volgar poesia, vol. 5 (Rome: Lorenzo Baseggio, 1730), 283.

35 "S. Francesco Saverio, invitato da Civan Re di Bungo, si portò a Corte in abito nobile con signorile corteggio di Odoardo Gama, Capitano delle Navi Portoghesi, seguito da molti Cavaglieri di quella Nazione, e fu accolto dal Re con segni di stima, e venerazione, né ricusò il 
a Buddhist bonze. The narrative woven by Tedeschi in La conversione alla santa fede is the result of a series of historical appropriations. Thus in order to understand the apologetic tone of the libretto and to distinguish the various voices that contribute to it, Tedeschi's sources of inspiration must be identified.

\section{The Genesis of Tedeschi's Libretto}

As was the convention with these "Japanese plays," Tedeschi's Japanese muse was found in the histories of the Society of Jesus. His argomento cites "Bartoli, Asia, parte p[rima]" as the source for his dramatic action. Referring to the volume on Asia in Daniello Bartoli's (1608-85) monumental Dell'istoria della Compagnia di Giesu, La conversione alla santa fede was thus drawn from Bartoli's account of Francis Xavier at the court of Ötomo Yoshishige. ${ }^{36}$ Complications arise, however, when considering Bartoli's own sources. While the historical accuracy of his prose has long been debated, ${ }^{37}$ the origin of this particular story has a clear literary lineage with its own set of obstacles. It is evident that Bartoli, and thus Tedeschi, based their own interpretation of events on the travel writings of the Portuguese merchant Fernão Mendes Pinto (1509-83). His Peregrinação, posthumously published in 1614, became one of the most popular books of the seventeenth century, noted as even rivalling Cervantes's Don Quijote. ${ }^{38}$ More of an "autobiographical romance," ${ }^{39}$ Mendes Pinto's exotic travelogue is heavily dramatized and, through its own rhetorical constructs,

Santo tal pompa per onor del Vangelo. Tenutasi quindi una Disputa da lui con un Bonzo dottissimo avanti il Re, questi rimase affezionato alla Santa Fede Christiana; Ma perch'egl'era allacciato in piaceri di Mondo, restò nell'antica Superstizione. Fu poi con spirito profetico predetto dal Saverio, che doppò molto tempo sarebbesi reso Cristiano. In fatti 27 anni doppo fu detto Re battezzato dal Padre Francesco Cabral Vice Provinciale della Compagnia di Gesù, e volle al Sagro Fonte il Nome di Francesco, per memoria venerabile di S. Francesco Saverio Apostolo del Giappone." Verbenio [Giovanni Tedeschi], La conversione alla santa fede delre diBungo giaponese (Bologna:Peri,1703), 2. Iam deeply indebted to Aaron Carpene for his assistance with the translations from the libretto that appear in this article.

36 Daniello Bartoli, Dell'istoria della Compagnia di Giesu: L'Asia (Rome: Varese, 1667), 163-69.

37 See Mattia Begali, "Daniello Bartoli," in Encyclopedia of Italian Literary Studies, ed. Gaetana Marrone, vol. 1 (New York: Routledge, 2007), 133-35.

38 Steven Gonzagowski, "The Subversion of Empire as Farce in Fernão Mendes Pinto's Peregrinação," in At Whom Are We Laughing?: Humor in Romance Language Literatures, ed. Zenia Sacks Da Silva and Gregory M. Pell (Newcastle: Cambridge Scholars Press, 2013): 31-40, here 32.

39 Joan-Pau Rubiés, Travellers and Cosmographers: Studies in the History of Early Modern Travel and Ethnology (Aldershot: Ashgate, 2007), 24-43. 
blurs fact with fiction. Yet, as noted by Rubiés, his sections on Japan have proven to be somewhat reliable, particularly in light of his entrance into the Society's novitiate in Malacca in April of $1554 .{ }^{40}$ We do know that Pinto and his fellow Portuguese merchants assisted Xavier in Bungo in 1551, and that Xavier did indeed meet with Ōtomo Yoshishige in September of the same year. ${ }^{41}$ However, the religious disputation that Mendes Pinto and Bartoli describe as occurring between Xavier and a Buddhist bonze named "Faisciondono,"42 appears to be but an invention. It is this very disputation that forms the basis of La conversione alla santafede and consequently raises questions as to the extent to which Tedeschi's own narrative voice resonates in the oratorio.

\section{Parte prima: Christianity as Light, Buddhism as Darkness}

[B]ut in the end, dear hopes, be consoled

to see at the river-mouth of Bungo

the harbor of faith and the triumph of the cross.

In the sea, which is always unstable, there is no fleeting fortune for those who hoped in heaven.

The tempests are calm, the waves are not troubling for those guided by faith. ${ }^{43}$

40 Rubiés, "Real and Imaginary Dialogues," 452. However, the influence of Mendes Pinto on subsequent biographers of Xavier must be noted. Henry J. Coleridge's nineteenth-century account of Xavier's life, for instance, notes discrepancies between Mendes Pinto's details and other sources, yet still regards the Peregrinação as an historical work. Consequently, research that relies heavily on Coleridge without consideration of these issues is problematic. See, for instance, John D. Young, Confucianism and Christianity: The First Encounter (Hong Kong: Hong Kong University Press, 1983), 12-22.

41 "I left Father Cosme de Torres and Juan Fernández in Yamaguchi with those who had become Christians and went to Bungo. The duke [Ōtomo Yoshishige] received me with great kindness, and I was much consoled by the Portuguese who had come there." Francis Xavier to his companions in Europe, from Cochin, January 29, 1552, in Letters and Instructions of Francis Xavier, 338.

42 Bartoli, Dell'istoria della Compagnia di Giesu, 167. . Spelled "Fasciondono" in La conversione alla santa fede.

43 Odoardo Gama (Duarte da Gama): "Ma consolate al fin, care speranze / Di vedere di Bungo in su la foce / Porto alla Fede, e trionfar la Croce. / Nel mar, ch'è sempre instabile, / Non v'è fortuna labile / Per chi nel Ciel sperò. / Son calme le tempeste, / Non son l'onde 
The oratorio opens with Xavier and the Portuguese captain-major Duarte da Gama ${ }^{44}$ approaching the "Harbor of Faith" (i.e. Funai). In the above aria, sung by the character of da Gama, the recurrent metaphor of a ship upon stormy seas is used to convey the "triumph of the cross" over the turbulence of heathenism. Da Gama characterizes Xavier as the captain of this emblematic ship, guiding infidels away from crashing waves through the divine light of God.

Just as among the billowing clouds

the rainbow smiles,

and joins the earth and heavens in peace:

So did the great Xavier come

from the very troubled waves

to quell the storms of impiety. 45

Xavier and da Gama then engage in a duet wherein they sing of their desire for the falling of unworthy Buddhist idols against the reign of the true faith. ${ }^{46}$ The concurrent scenario at the Japanese court is that of the king of Bungo (Ōtomo Yoshishige) and his "minister of the sacred altars" (ministro de' sagri altari) awaiting the arrival of Xavier. Fasciondono, described in Tedeschi's list of interlocutors as a "Japanese bonze," is characterized as an individual of the vilest order, employing crude vocabulary and displaying such arrogance to inspire disgust in the audience/congregation. His distrust of Xavier manifests itself in an anti-Christian tirade through which we are made aware of the king's readiness to accept Christ. This secondary religious disputation between the king and Fasciondono is embodied in a da capo aria revolving around the metaphorical dichotomy between light and darkness, in which Japan is likened to a cave of eternal night untouched by the bright rays of Christianity.

moleste, / Per chi la Fè guidò." Verbenio, La conversione alla santa fede, 3. For the Italian quotes from the libretto, spelling and punctuation have been modernized.

In 1551, Duarte da Gama travelled to Bungo from Lampacao (an historical island of the Pearl River Delta) on the Kwangtung coast, where he visited the ports of Hide and Funai. He is noted for returning to China in November of that year, taking with him several Japanese including an envoy of Ōtomo Yoshishige. See Charles R. Boxer, Fidalgos in the Far East, 1550-1770 (Hong Kong: Oxford University Press, 1968), 29-30.

45 Odoardo Gama (Duarte da Gama):“[...] Come là tra le nubi ondeggianti / Ride l'arco balen, / E tra la terra, e 'l Ciel la pace fa: / Così fuor di marosi inconstanti / Qua venne il gran Savier / Le procelle a sedar dell'Empietà." Verbenio, La conversione alla santa fede, 4-5.

46 Ibid., 5 . 
Let my heart be consoled, since the sun has finally arrived in the darkness of these caves.

Let my soul be comforted, he [the sun] wants to have a new day here, through his permanence. ${ }^{47}$

After being asked by the king about his thoughts on the arrival of the missionaries, Fasciondono, through a da capo aria, rejects this light, depicting it as nothing but an illusion of foreign strangers.

How many stars in their thousands appear in the sky above the poles! How many suns bestow the splendor of their golden light upon one's eyes! But the luminous deceits of a colored cloud are unveiled by the wind, and the false golden light disappears once more. ${ }^{48}$

This perceived impermanence of the foreign light causes Fasciondono to doubt the fame of Xavier in Japan, instead fuelling his desire to dissuade the king. Indeed, his description of Xavier as a barefoot beggar is based on historical facts. ${ }^{49}$ Xavier's initial display of apostolic poverty worked against him during his first visit to Yamaguchi (November, 1550), where the daimyo Ouchi Yoshitaka (1507-51) had taken great offence at his shabby appearance. ${ }^{50}$ To this extent, those who opposed the missionaries perpetuated this image of a

47 Re di Bungo (Ōtomo Yoshishige): "Core consólati, / Che a queste grotte / Di oscura notte / È giunto il Sol. / Alma confòrtati, / Che nuovo giorno / Col suo soggiorno / Aver qui vuol.” Verbenio, La conversione alla santa fede, 5 .

48 Bonze (Fasciondono): "Quante in Ciel appaion stelle / Sopra i poli a mille a mille! / Quanti soli alle pupille / Pompa fan di luci d'or! / Ma gl'inganni luminosi / D'una nube colorita / Scuopre il vento, e la mentita / Luce d'or sparisce ancor." Verbenio, La conversione alla santa fede, 6 .

49 “[...] Ma poi / Esso è mendico, e scalzo il piè s'aggira." Verbenio, La conversione alla santa fede, 6 .

$5^{0}$ Jurgis Elisonas, "Christianity and the Daimyo," in The Cambridge History ofJapan, ed. John Whitney Hall, vol. 4 (Cambridge: Cambridge University Press, 1991), 313. Xavier returned to Yamaguchi in April of ${ }^{1551}$, this time attired in his best clothes and offering sumptuous gifts to Yoshitaka, who was so impressed by the European display that the Jesuits were 
threadbare foreigner, much like Fasciondono in La conversione alla santa fede. Fasciondono, following the above aria, then rushes into a recitative through which he portrays Xavier as a wizard, a liar, and a lunatic who "enchants with his words, $[. .$.$] fascinates with his eyes, and [...] flatters the people." { }^{51}$ Thus the bonze expresses his "fear [of] deceit from afar [...] [and] deceptions close by," and accuses the king of being advised by "too credulous a heart." ${ }^{2}$ The parte prima of the oratorio concludes with Xavier and da Gama preparing to enter the court of the king.

Tedeschi's libretto is undeniably imbued with a sense of his own apologetic spirit. As Bartoli's Dell'istoria della Compagnia di Giesu does not contain this particular disputation between Fasciondono and the king, we are able to distinguish here the results of Tedeschi's literary invention. By identifying Tedeschi's own voice in the libretto, we understand more clearly his intention - that is, to deepen and dramatize the theological rifts alluded to in Bartoli. Introducing an underlying dispute between Fasciondono and the king, Tedeschi moves his audience to abhor the bonze. The faithful of Faenza (the oratorio's intended spectators) were presented with an image of a virtuous Japanese king whose only response to the bonze's doubts is to deepen his own growing sense of Christian faith, and to warn the heathen against the degeneration of excessive prudence into crime. ${ }^{53}$ The characterization of Fasciondono as a mouthpiece of "Buddhist" vainglory is further developed in the oratorio. In so doing, the libretto demonstrates a naïve simplification and conflation of varying sects of Buddhist belief and practice in sixteenth-century Japan. Furthermore, as we will see in the parte seconda, the transformation of Xavier from a passive to an active character in the main disputation (between Xavier and Fasciondono) demonstrates the apologetic voice of Tedeschi as Xavier.

\section{Parte seconda: Representations of Buddhism and Theological Disputation}

The second half of the oratorio opens with a recitative by da Gama who sings of a fanfare of trumpets and "proud timbales" as they approach the royal palace

given permission to evangelize in the region. See Kerstin-Katja Sindemann, "Japanese Buddhism in the $16^{\text {th }}$ century: Letters of the Jesuit Missionaries," Bulletin of PortugueseJapanese Studies 2 (2001): 111-33, here 116.

$5^{1}$ Bonze (Fasciondono): “[...] Incanta con sue voci, / Affascina co' i lumi, / Per il volgo ha lusinghe." Verbenio, La conversione alla santa fede, 6 .

$5^{2}$ Verbenio, La conversione alla santa fede, 6, 7 .

53 Ibid., 7 . 
of the king. ${ }^{54}$ The opening of the parte seconda with a corresponding musical display is certainly likely. The only marginal instruction about Laurenti's instrumentation in the libretto is a reference to the use of "trumpets, and many instruments" (con Trombe, e molti strumenti) to accompany a short chorus of Portuguese soldiers in the parte prima.${ }^{55}$ While lacking any kind of specificity, this does however indicate the importance and scale of the performance, suggesting a musical display of some grandeur. ${ }^{56}$ It is against this backdrop of pomp and circumstance that Fasciondono protests the arrival of Xavier and the European faith, claiming it to be but "futile considerations, unnecessary thoughts! The true wisdom is to honor Siacca [Shaka] and Amida, our gods. ${ }^{n 7}$ Here, he is referring to Shaka (Shakyamuni), the historical Buddha upon whose teachings Buddhism was founded, and Amida (Amitābha), a cosmic Buddha described in the scriptures of Mahāyanna Buddhism, who is also the principal Buddha in the various schools of Pure Land Buddhism (especiallyJōdo-shū andJōdoShinshū). A discussion of the Buddhist pantheon does not in fact take place in Bartoli's account of Fasciondono's tirade. Thus the performative representation of Buddhism, and the theological disputation that occurs between the bonze and Xavier in La conversione alla santafede, is a construction of Tedeschi's own apologetic agenda.

Upon arising before the king, Xavier sings an aria, proclaiming to him in the presence of Fasciondono that

[the] King of the Kings is God.

All of nature revolves around him,

as a center of love,

from him all of nature emanates

and to him it returns. ${ }^{58}$

\footnotetext{
$54 \quad$ Ibid., 9 .

55 Ibid., 4 .

56 La conversione alla santa fede is listed in Claudio Sartori's catalogue as one of only two oratorios performed in Faenza during 1703. While no performance date is listed, the absence of oratorios between 1703 and 1719 indicates that these were no doubt significant events for the religious institutions of Faenza. Claudio Sartori, I libretti italiani a stampa dalle origini al 180o: Catalogo analitico con 16 indici, vol. 6/1 (Cuneo: Bertola e Locatelli, 1993), 41.

57 "Vani riguardi, inutili pensieri! / Son bene i sensi veri, / Sciacca e Amida onorar, li nostri Numi." Verbenio, La conversione alla santa fede, 10.

58 “[...] e Re de' Regi è il Dio. / Tutta a lui come a centro d'amore / La Natura d'intorno si gira, / Da lui parte, ed a lui ritornò." Ibid., 11.
} 
The king becomes inflamed with the desire to convert and laments the wayward condition of the Japanese nation in an aria:

And until now we were left

in the dark? And even that sun

wants to disappear from Japan now? ${ }^{59}$

The unintended irony in this, unbeknownst to Tedeschi, is that Amida refers to "the Buddha of infinite light" (Amitābha Buddha). The importance of the Nembutsu (primarily in Jōdo-shu, the Pure Land School), or the pursuit of salvation through the recitation of the name of Amida, was noted by Xavier and later Jesuit missionaries. ${ }^{60}$ In effect, this chanting of Namu, Amida Butsu (Hail, Amida Buddha! or Save us, o merciful Buddha), invokes the awakening of infinite light, a concept that resonates with Tedeschi's own metaphorical use of the sun to describe the illuminating power of his Christian God. The Jesuit interpretation of the Nembutsu appears to be replicated in Tedeschi's use of a chorus of bonzes. They refute Xavier's expression of Christian faith, invoking the salvation of Shaka and Amida:

Long live Sciacca, long live Amida, our gods, and only gods:

here on earth and in the heavens

let all that is good be ascribed to them. ${ }^{61}$

The inclusion of Shaka in Tedeschi's performative interpretation of the Nembutsu corresponds to descriptions of the practice given by Xavier, as well as by other Jesuits such as Alessandro Valignano (1539-16o6), visitor of the East Indies: "No matter what sins one has committed, [bonzes] [...] chant the name

59 “E Noi fin'or restammo / In buia notte? E vuole / Al Giappone fin or sparir quel Sole?" Ibid., 12.

6o "[I]f they invoke the founders of these sects [Shaka and Amida], they will free them from all their pains, even though they do no penance; and that this will happen if, with great faith and without any shadow of doubt, they invoke those in whom they place all their hopes and confidence": Francis Xavier to his companions in Europe, from Cochin, January 29, 1552, in Letters and Instructions of Francis Xavier, 328-29.

61 Choro de' Bonzi [Chorus of Bonzes]: "Viva Sciacca, Amida viva, / Nostri numi, e numi soli: / Qui nel suol, e su nei Poli / Tutto a loro il ben s'ascriva." Verbenio, La conversione alla santa fede, 13 . 
of Amida or Shaka, and so long as one truly believes in the virtue of this act, those sins will be cleansed." ${ }^{2}$ The conceptualization of Shaka and Amida as Japanese "gods" is problematic and indicates a clear attempt to interpret nonChristian worship through the lens of Christian practice. To this extent, Xavier's initial encounter with Buddhism was colored by a belief in the existence of an omnipotent, omnipresent singular deity of Japan that corresponded to his Christian God. ${ }^{63}$ Following his time in Bungo, Xavier penned a famous letter from Cochin in 1552, in which he identified Shaka and Amida as the primary figures of Buddhist worship. ${ }^{64}$ It should be noted, however, that Xavier's recognition of these figures transformed from "men of ancient times" in 1549 to "pure inventions of the demons" in $1552 .{ }^{65}$ This distinction between cosmic deity and mortal man is also addressed in La conversione alla santa fede during the great theological dispute. As identified by Abé, the primary misunderstanding in this Jesuit pursuit of identifying Japanese "gods" was the assertion that Buddhist deities were central to their doctrine in the same way that God was at the very core of Christianity. ${ }^{66}$ By approaching the Japanese through the lens of Christianity, they "failed to understand that there was a mystical law at the core of Buddhism and that Shaka or Amida was the individual who was believed to have fulfilled this law and enlightened himself as a Buddha." ${ }^{67}$

\section{Tedeschi's Conflation of Buddhism}

In all of Japan, the "king of Bungo" is regarded as one of the most intelligent men. It is a known fact too, that among laymen he is best acquainted with, and has the best grasp of, the sects, especially that of the Zen, which is the most important of them all. He has the rank of a choro in that sect, corresponding roughly with that of a doctor. ${ }^{68}$

62 Kinryū Shizuka, "The $I k k \bar{o}-s h \bar{u}$ as Portrayed in Jesuit Historical Documents," trans. William Londo, in Rennyo and the Roots of Modern Japanese Buddhism, ed. Mark L. Blum and Shin'ya Yasutomi (Oxford: Oxford University Press, 2006): 72-82, here 76.

63 Takao Abé, The Jesuit Mission to New France: A New Interpretation in the Light of the Earlier Jesuit Experience in Japan (Leiden: Brill, 2011), $5^{2}$.

64 Letters and Instructions of Francis Xavier, 328.

65 Ibid., 298; 337. Emphasis added.

66 Abé, Jesuit Mission to New France, 53.

67 Ibid.

68 Francisco Cabral to Everard Mercurian, October 15, 1587. See Josef F. Schütte, Valignano's Mission Principles for Japan, vol. 2/II, trans. John J. Coyne (St. Louis: Institute of Jesuit Sources, 1985), 160 . 
Ōtomo Yoshishige, during the twenty-seven years between his meeting with Xavier and his formal baptism, was an ardent practitioner of Zen Buddhism. Following the relocation of his court from Funai to Usuki in 1562, a temple was constructed and a renowned Zen master was summoned to take up residency. ${ }^{69}$ It is no surprise that he is known more commonly today by the Buddhist name of Sōrin (宗麟), which he adopted upon his nominal retirement. The significance of this lies in the fact that Tedeschi's representation of Buddhism in $L a$ conversione alla santa fede, although unknowingly, is primarily derived from the schools of Pure Land Buddhism. The vocal, and thus external, invocation of Amida in the oratorio would suggest more specifically the sect of Jōdo-shu, which places greater importance on recitation of the Nembutsu than its contemporary reformed sect of Jödo Shinshü (True Pure Land Buddhism). ${ }^{70}$ The characterization of Fasciondono and the Chorus of Bonzes as simply "Japanese monks," thus conflates the deep sect divisions of Buddhism present in sixteenth-century Japan, and asserts an oversimplified image of theological unity. Tedeschi's emphasis on the central worship of Amida, for instance, would not have been found in Yoshishige's own beliefs and practices. In contrast, the letters of Xavier and the chapters of Bartoli on Japanese religion both reflect the existence of different sects. ${ }^{71}$ Indeed, even Bartoli, in spite of his factual flaws, describes seven to twelve different "institutions" of Buddhism that are so disparate that they appear as divided bodies rather than "members united in the same religion."72 Zen, as a contemplative sect which emphasizes simplicity and self-discipline, can be clearly distinguished from Tedeschi's performative representations. Rejecting more traditional modes of worship, Zen aspires to Shaka, the historical

69 Dumoulin, Zen Buddhism, 264.

$70 \quad J \bar{o} d o-s h \bar{u}$, Jōdo Shinshu, and $I k k \bar{o}-s h \bar{u}$, all taught an eschatological pursuit of salvation in the Saihō jōdo (the Pure Land or the Paradise in the West). The primary doctrinal distinction between Pure Land and True (Shin) Pure Land Buddhism lies in the latter's conception of faith (shinjin). Shin Buddhism advocates the abandonment of personal power (jiriki), and the acceptance of tariki, the notion of faith as a gift from another power (i.e., Amida's gift to mankind). Compared to Jödo-shū, salvation in Shin Buddhism is found in a 'moment of faith,' and not at the moment of death. See Esben Andreasen, Popular Buddhism in Japan: Shin Buddhist Religion and Culture (New York: Routledge, 1998), 9-12.

71 In letters of 1549 and $155^{2}$, Xavier distinguishes these sects by the color of the robes worn by their monks. In the letter of 1552 , Xavier identifies "nine kinds of doctrine" that most likely refer to the nine principal sects of Tendai, Shingon, Yūzū Nembutsu, Jōdo Shinshū, Rinzai Zen, Sōtō Zen, Ikkō-shū, Hokke-kei Bukkyō (Nichiren), and Ji-shū. See Letters and Instructions of Francis Xavier, 328.

72 Bartoli, Dell'istoria della Compagnia di Giesu, 132. 
Buddha, as an exemplar of spiritual awareness through individual meditation. Similarly, Zen paintings from this period display a select number of deities who were utilized more as inspirational models than as idols to be worshipped. For Yoshishige, a follower of the Rinzai school of Zen, ${ }^{73}$ Shaka was viewed as a mortal man who was "committed to solitary and strenuous self-sacrifice in his quest for enlightenment, rather than as an abstract symbol of Buddhahood."74 However, Tedeschi's oversights, aside from any literary fancy, are based in Bartoli's own inaccuracies. While Bartoli acknowledges a distinction between cami (kami or Japanese deities) and fotoches (hotoke or Buddhas), he does not sufficiently explain these concepts, lacking some of the depth found in other Jesuit documents. ${ }^{75}$ Nevertheless, to take significant creative liberties with their historical adaptations was a common trend for playwrights and librettists writing "Japanese plays" throughout the seventeenth and eighteenth centuries. ${ }^{76}$ In this way, the exotic narrative of La conversione alla santa fede provided a captivating basis from which Tedeschi himself could engage in theological debate with the imagined ("Buddhist") Other through the mouth of Francis Xavier.

\section{Religious Disputation between Fasciondono and Xavier}

In response to the "Nembutsu chorus," Xavier, in the parte seconda, questions the legitimacy of these Japanese "gods." By asserting that Shaka and Amida are "subject to all the laws of nature" and the time between moments of life and death, he contrasts the immortality of the Christian God with the mortality of heathen idols. ${ }^{77}$ By virtue of said mortality, he then questions how then they can offer eternity (the concept of the immortal soul and a Christian afterlife)

73 Zuiho-in (瑞峯院), one of twenty-two sub-temples within northern Kyoto's Daitoku-ji (大徳寺) Temple, was founded by Yoshishige in 1546. Daitoku-ji is one of fourteen autonomous branches of the Rinzai school of Japanese Zen.

74 Patricia J. Graham, Faith and Power in Japanese Buddhist Art, 1600-2005 (Honolulu: University of Hawai'i Press, 2007), 144. See also Helmut Brinker, "Shussan Shaka in Sung and Yüan Painting," Ars orientalis 9 (1973): 21-40.

75 Bartoli states the existence of various religions in Japan: Sinto (Shintoism), Budso (Buddhism), and Atheism (divided into those who worship the sun and moon, kami, and those who revere animals or the devil). In a letter to Claudio Acquaviva (1543-1615) from Nagasaki on August 27, 1585, Luís Fróis explains this distinction between kami and hotoke, specifying that Shaka and Amida are Buddhas, while the kami include various deities of the sun, the harvest, war, etc. See Abé, Jesuit Mission to New France, 53.

76 Immoos, “Japanese Themes in Swiss Baroque Drama," go.

77 Verbenio, La conversione alla santa fede, 13 . 
to Fasciondono and his bonzes. ${ }^{78}$ This interconnectedness of a personal soul, salvation, and the afterlife was established from the very outset as a crucial topic for religious disputations between Jesuit missionaries and the Buddhist monks they encountered. Just as Xavier here questions the validity of the Saiho jôdo (the Pure Land) in the oratorio, so too did Valignano, in his Catechismus christianae fidei (1586), ${ }^{79}$ reject the Pure Land conception of the afterlife upon grounds of its overly-corporeal nature. ${ }^{80}$ The rest of Xavier's recitative speaks to the omnipotence, righteousness, and mercy of the one true Christian God, claiming that those who do not yield to his light are but savages. Fasciondono responds through arguments of reason, attacking these notions of godly omnipotence and righteousness. Formal Buddhist refutations of Christianity began to be published by the turn of the seventeenth century, which similarly sought to deconstruct the identity of Daiusu (or Deusu). ${ }^{81}$ Suzuki Shōsan (1579-1655) and Asai Ryōi's (d.1691) Kirishitan hakyakuron den (Christians demolished: tract and glosses), for instance, defines Daiusu as the Christian creator of all things and the Lord of heaven and earth. Their counterarguments against the foreign faith reflect a myriad of perceived inconsistencies, such as the delay

78 The Christian concept of the immortal soul was a problematic one for the Jesuits in their theological debates. Zen adherents, for instance, denied the existence of the personal soul, a theme that would continue to define the sect in Jesuit writings. See Georg Schurhammer, Die Disputation des P. Cosme de Torres (Tokyo: OAG, 1929), 5o. Indeed Cosme de Torres (1510-70) warned Xavier that "Zen priests ask questions which even Thomas and Scotus could not answer to their satisfaction." Torres to Xavier from Yamaguchi, October 20, 1551, in George Elison, Deus Destroyed: The Image of Christianity in Early Modern Japan (Cambridge, MA: Harvard University Press, 1973), 40.

79 Alessandro Valignano, Catechismus christianae fidei, in quo veritas nostrae religionis ostenditur et sectae Iaponenses confutantur [Catechism of the Christian faith, in which the verity of our Christian religion is demonstrated and the Japanese sects refuted] (Lisbon: Antonius Riberius, 1586).

8o For Valignano, the soul of the deceased was comprised of only three powers: memory, intellect, and will. As the Christian afterlife was a purely spiritual realm, the (Buddhist) Pure Land, a place occupied by golden bodies with human characteristics, was simply implausible. See James Baskind, "Emptiness and Nothingness in Habian's Critique of Buddhism," in The Myōtei Dialogues: A Japanese Christian Critique of Native Traditions, ed. James Baskind and Richard Bowring (Leiden: Brill, 2015), 16-30, here 18.

81 The Jesuit adaptation of the Latin word "Deus" for use in Japanese translations of the catechism. For a discussion of the complications with translating the name of the Christian God in mid-sixteenth-century Japan, see Sangkeun Kim, Strange Names of God: The Missionary Translation of the Divine Name and Chinese Responses to Matteo Ricci's "Shangti" in Late Ming China, 1583-1644 (Bern: Peter Lang, 2004), 77-86. 
in Christianity's discovery of the New World and the actions of this supposedly all-knowing God permitting the growth of other religions which had saved sentient beings for thousands of years. Indeed they assert that "this Deusu is a stupid Buddha [god]. Could anything be so bereft of reason?"82 Fasciondono similarly refutes Christianity through the notion of evil in the following recitative:

But how did he condemn mortals,

his dearest creatures,

to so many deaths?

Where are love and righteousness in him? ${ }^{83}$

This perceived incompatibility of an all-loving God with the existence of evil was a recurring and problematic point of contention for the Jesuits during theological debates with Buddhist monks. Similarly the concept of hell and eternal damnation was incomprehensible through the lens of Buddhist compassion and mercy for even the most debased of people. ${ }^{84}$ Xavier, both the historical and the performative (in La conversione alla santa fede) character, references original sin, emphasizing that evil forms through one's own faults. In a corresponding aria, Xavier sings of the immortality of the soul, and the necessity of penance in light of Christ's love demonstrated through his death upon the cross. ${ }^{85}$ Thus the king proclaims he is guided by the light of God and the oratorio draws close to its end.

\section{Parte finale: Foretelling the Conversion of Ōtomo Yoshishige}

As expressed in the oratorio's argomento, Yoshishige flirted with Christianity for twenty-seven years before his formal baptism. The circumstances of this

82 Translated in William Theodore de Bary et al., eds., Sources ofJapanese Tradition, 16oo-20oo, vol. 2 (New York: Columbia University Press, 2005), 181-84. This was a common tone adopted in the anti-Christian literature circulating in the seventeenth century. This is perhaps most famously embodied in Fabian Fucan's (Fukansai Habian, 1565-1621) Ha Daiusu (Deus Destroyed or Refutation of Deus, 1620), in which the ex-Christian apologist turned Buddhist monk seeks to demythologize Christianity and highlight the destructive nature of that religion. An English translation is presented in Elison, Deus Destroyed, 259-91.

83 "Ma come a tante morti / Condannò li mortali/ Sua più cara fattura? / Dov'è l'Amor, e la Giustizia in lui?" Verbenio, La conversione alla santa fede, 13.

84 Olof G. Lidin, Tanegashima: The Arrival of Europe in Japan (Copenhagen: NIAs Press, 2002), 45; René Fülöp-Miller, The Jesuits: A History of the Society of Jesus (New York: Capricorn Books, 1963), 213-15.

85 Verbenio, La conversione alla santa fede, 13-14. 
decision are complex, and his delay reflects predicaments of a simultaneously sociocultural, political, economic, and religious nature. ${ }^{86}$ However, Tedeschi accounts for this delay by asserting that the "fruit of [the king's] faith is not yet ripe" (Il frutto di tua fè non è maturo ancor).${ }^{87}$ So as to fulfil Xavier's foretelling, da Gama sings an aria extrapolating upon Tedeschi's theme of spiritual immaturity:

The king, faithful in heart, is not yet faithful in mind!

And does he not see the light, but feels the ardor? Ah yes, how the heart hardens while pursuing the softness of worldly pleasures, and the mind darkens amidst the heavenly rays. ${ }^{88}$

Following Xavier's vision of the king bathing in well-being at the font, the oratorio concludes with a da capo chorus of Portuguese soldiers, Xavier, da Gama, and finally a tutti declaration to the country of Japan.

Chorus of Portuguese:

Xavier/da Gama:

Tutti:
Yes, faith will win the heart of such a great king, which now is of stone. ${ }^{89}$ Arrow of holy love, blood of the Redeemer they know how to win the rebel souls to God. ${ }^{90}$ Faith impetrates a port in the middle of the sea. ${ }^{91}$ (Yes, faith will win, etc.)

86 See Michael Cooper, Rodrigues the Interpreter: An Early Jesuit in Japan and China (New York: Weatherhill, 1974), 45-50; James Murdoch and Isoh Yamagata, A History of Japan, vol. 2 (Kobe: Chronicle, 1903), 73-81.

87 As sung by Xavier. Verbenio, La conversione alla santa fede, 13-14.

88 "Il Re nel Cor fedele, / Non fedel nella mente! / Ei la luce non vede, e l'ardor sente? / Ah sì che troppo molle / Ne' vizi il Cor s'indura, / E tra lumi del Ciel la mente oscura." Verbenio, La conversione alla santa fede, 15 .

89 Coro de Lucitani: “Vincera sì la fè / Il Cuor di sì gran Re, / Ch'or è di pietra." Ibid., 16.

90 "Strale del Santo Amor, / Sangue del Redentor, / L'Alme rubelli a Dio / Sanno espugnar." Ibid.

91 "E Porto in mezzo al Mar / La Fede impetra." Ibid. This description of a port in the middle of the sea is most likely a reference to the nation of Japan as a set of islands. 
The meeting of a curious Otomo Yoshishige with Francis Xavier in ${ }^{1551}$ represents one of the most eventful moments of intercultural contact in the sixteenth century. Despite the brevity of Xavier's time in Bungo and his death soon thereafter, the legacy of Yoshishige resounded throughout early modern Europe. Not only was he one of the most ardent activists for Xavier's beatification, but he also contributed to the Japanese embassy sent to Europe in $1582 .{ }^{92}$ Laurenti and Tedeschi's La conversione alla santa fede in many ways can be seen as bringing to life the intrigue of this encounter through music. However, the various layers of theological and performative rhetoric, demonstrated in this article, are central to interpreting the function of the oratorio. The multiple levels of Eurocentric bias (from Xavier to Mendes Pinto to Bartoli to Tedeschi) prevent any genuine interpretation of Buddhist ideologies, and the final result in the libretto is a fanciful appropriation of fictionalized history. Nevertheless, the performative representation of Buddhism and its friction with Christianity, for all its shortcomings, facilitates the exploration of number of key themes that dominated the Jesuit-Buddhist disputations of the mid-sixteenth century. Moreover, Tedeschi's characterization of Xavier as an active participant in theological disputation (as opposed to the passive role in Bartoli) enabled his own didactic agenda of reinforcing the faith of the Jesuit congregation in Faenza. As in the majority of these baroque "Japanese plays," the exoticism of their narrative functioned both as entertainment as well as a mirror through which Catholic Europe could see an exemplary reflection of its own faith. ${ }^{93}$ Furthermore, La conversione alla santa fede offers us a remarkable example of an oratorio composed during the period of the "ban" on opera by Clement XI. It is to be hoped that a fortunate finding in the years to come will remedy the lamentable lack of a musical score.

92 See Michael Cooper, The Japanese Mission to Europe, 1582-169o: The Journey of Four Samurai Boys through Portugal, Spain and Italy (Kent: Global Oriental, 2005). 